\title{
The relationship between (sub)tropical climates and the incidence of COVID-19
}

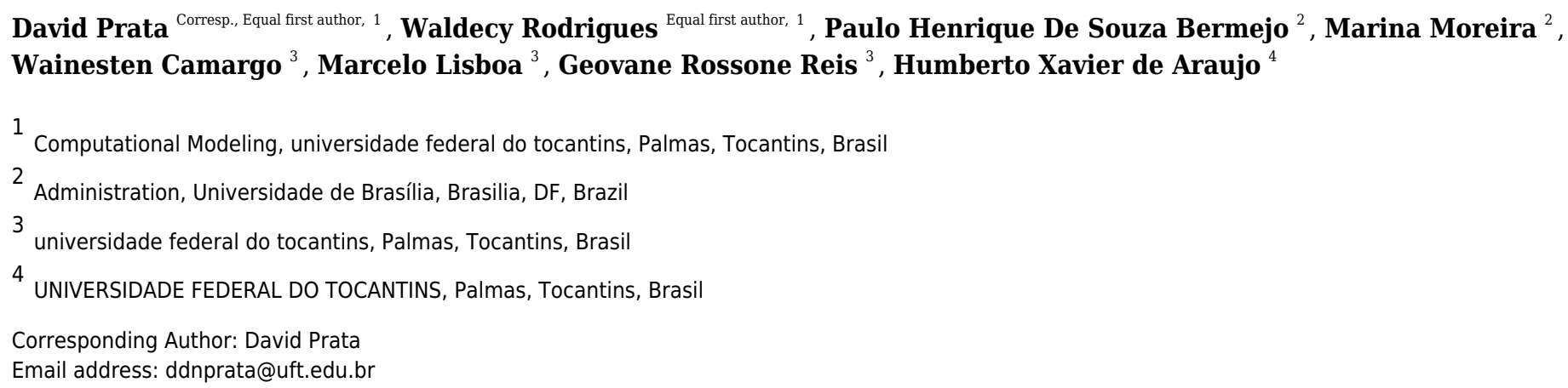

This work explores (non)linear associations between relative humidity and temperature and the incidence of COVID-19 among 27 Brazilian state capital cities in (sub)tropical climates, measured daily from summer through winter. Previous works analyses have shown that SARS-CoV-2, the virus that causes COVID-19, finds stability by striking a certain balance between relative humidity and temperature, which indicates the possibility of surface contact transmission. The question remains whether seasonal changes associated with climatic fluctuations might actively influence virus survival. Correlations between climatic variables and infectivity rates of SARS-CoV-2 were applied by the use of a Generalized Additive Model (GAM) and the Locally Estimated Scatterplot Smoothing LOESS nonparametric model. Tropical climates allow for more frequent outdoor human interaction, making such areas ideal for studies on the natural transmission of the virus. Outcomes revealed an inverse relationship between subtropical and tropical climates for the spread of the novel coronavirus and temperature, suggesting a sensitivity behavior to climates zones. Each 1 ㅇ $\mathrm{C}$ rise of the daily temperature mean correlated with $\mathrm{a}-11.76 \%$ (t $=-5.71, p<0.0001)$ decrease and a 5.66\% $(t=5.68, p<0.0001)$ increase in the incidence of COVID-19 for subtropical and tropical climates, respectively. 
1 Title: THE RELATIONSHIP BETWEEN (SUB)TROPICAL CLIMATES AND THE

2 INCIDENCE OF COVID-19

3 One-Sentence Summary: This report explores (non)linear relationships of climatic factors and

4 COVID-19 in (sub)tropical regions of Brazil.

5 Authors:

6 David N. Prata ${ }^{1}$, Waldecy Rodrigues ${ }^{1}$, Paulo H. De Souza Bermejo ${ }^{2}$, Marina F. Moreira ${ }^{2}$,

7 Wainesten Camargo ${ }^{1}$, Marcelo L. Rocha ${ }^{1}$, Geovane R. Reis ${ }^{1}$, and Humberto X. Araujo ${ }^{1}$

8

9 Affiliations:

$10{ }^{1}$ Institute of Regional Development, The Graduate Program of Computation Modelling, Federal

11 University of Tocantins. Quadra 109 Norte | 77001-090 | Palmas/TO - Brazil

$12{ }^{2}$ Research and Development Center for Public Sector Excellence and Transformation (NExT) of

13 the Department of Administration, Federal University of Brasilia - Brazil.

15 Corresponding author:

16 Name: David Nadler Prata Ph.D., Associate Professor

17 Department of Computation Modelling

18 Institute of Regional Development

19 Universidade Federal de Tocantins

20 Quadra 109 Norte | 77001-090 | Palmas/TO - Brazil

21 Tel 55-63-981144040

22 Fax 55-63-3229-2020

23 E-mail: ddnprata@uft.edu.br (D Prata)

24

25 
28

29

\title{
THE RELATIONSHIP BETWEEN (SUB)TROPICAL CLIMATES AND THE INCIDENCE OF COVID-19
}

\begin{abstract}
This work explores (non)linear associations between relative humidity and temperature and the incidence of COVID-19 among 27 Brazilian state capital cities in (sub)tropical climates, measured daily from summer through winter. Previous works analyses have shown that SARS-CoV-2, the virus that causes COVID-19, finds stability by striking a certain balance between relative humidity and temperature, which indicates the possibility of surface contact transmission. The question remains whether seasonal changes associated with climatic fluctuations might actively influence virus survival. Correlations between climatic variables and infectivity rates of SARS-CoV-2 were applied by the use of a Generalized Additive Model (GAM) and the Locally Estimated Scatterplot Smoothing LOESS nonparametric model. Tropical climates allow for more frequent outdoor human interaction, making such areas ideal for studies on the natural transmission of the virus. Outcomes revealed an inverse relationship between subtropical and tropical climates for the spread of the novel coronavirus and temperature, suggesting a sensitivity behavior to climates zones. Each $1^{\circ} \mathrm{C}$ rise of the daily temperature mean correlated with a $-11.76 \%(\mathrm{t}=-5.71, \mathrm{p}<0.0001)$ decrease and a $5.66 \%(\mathrm{t}=5.68, \mathrm{p}<0.0001)$ increase in the incidence of COVID-19 for subtropical and tropical climates, respectively.
\end{abstract}




\section{Introduction}

9 The novel coronavirus (COVID-19), is caused by the severe acute respiratory syndrome coronavirus 2 (SARS-CoV-2), and due to its high contiguousness and widespread, it has officially been declared a pandemic by the World Health Organization (WHO) on March 11, 2020. As of November $18^{\text {th }}, 2020$, more than $1.3 \mathrm{mi}$ deaths by COVID-19 were confirmed based on $55 \mathrm{mi}$ confirmed cases in 219 countries (WHO, 2020).

In Brazil, the COVID-19 pandemic began on February 26 ${ }^{\text {th }}, 2020$, in São Paulo (subtropical city) (Saúde, 2020). After 43 days, it already killed more people than H1N1, dengue, and measles combined throughout 2019 (Costa, 2020). In April, the health system of the city of Manaus (capital of Amazonas state), collapsed, followed by the funerary system (Campbell, 2020).

The spread of the virus from temperate to tropical (Auler et al., 2020) regions subverted the expectation (Bukhari \& Jameel, 2020)(Liu et al., 2020)(Xie \& Zhu, 2020)(Zhu et al., 2020)(Prata et al., 2020)(Núñez-Delgado, 2020)(Yip et al., 2007)(Thai et al., 2015)(Ng et al., 2014)(Lowen \& Steel, 2014)(Bi et al., 2007)(Barreca \& Shimshack, 2012)(Moriyama \& Ichinohe, 2019)(Casanova et al., 2010)(Wang et al., 2018)(Xu et al., 2020) that the virus would not spread as efficiently in warmer climates. Debunking this hypothesis, studies as of (Kratzel et al., 2020) have indicated that Sars-CoV-2 incubation has the highest predicted half-life at $30^{\circ} \mathrm{C}$, much higher than originally believed. Other experiments have shown that the survival of Sars-CoV-2 is roughly five times more likely in humid conditions than in dry conditions (Bhardwaj \& Agrawal, 2020). As of midApril 2020, the world has seen a surge in the number of cases in regions with mean temperatures above $18^{\circ} \mathrm{C}$, like Brazil.

Evidence suggests that Sars-CoV-2 finds stability in striking a balance between relative humidity and temperature, which indicates the possibility of surface contact transmission. The question 
71 remains whether seasonal changes associated with climatic fluctuations might actively influence

72 virus stability and survival. Surface contact transmission evaluations have revealed that this

73 method has a significant impact on virus transmission (Casanova et al., 2010)(van Doremalen et

74 al., 2013). Temperature and humidity variations have also been proven to influence SARS-CoV-2

75 stability and survival on surfaces (Duan et al., 2003). Among other factors, depending on

76 temperature and humidity, the infectious capacity of the virus can persist on surfaces for anywhere

77 from a few hours to several days (van Doremalen et al., 2013).

78 Regardless the great number of studies modeling the effects of meteorological conditions on

79 COVID-19 transmission conducted worldwide, findings concerning the relationship of meteorological conditions and COVID-19 transmissibility are still controversial (Auler et al., 81 2020).

82 This study may help health policymakers apply knowledge about seasonality, infection prevention,

83 and control to prevent local transmission and slow the spread of the novel coronavirus to 84 (sub)tropical climates (Bedford et al., 2020). Specially, this research pursue the following 85 question: seasonal changes associated with climatic factors fluctuations as defined by Köppen 86 climate types might actively influence virus survival? Brazil's considerable area has allowed 87 researchers to study different climates within one nation. Warmer climates allow for more frequent 88 outdoor human interaction, making such places ideal for studies on the natural transmission of the 89 virus. The research design is presented in Fig. 1.

\subsection{Study Area}


94 The study included 27 cities, all state capitals of Brazil, covering longitudes from $34^{\circ} 51^{\prime} 40^{\prime \prime} \mathrm{W}$ 95 to $67^{\circ} 48^{\prime} 27^{\prime \prime} \mathrm{W}$ and latitudes from $8^{\circ} 45^{\prime} 43^{\prime \prime} \mathrm{N}$ to $30^{\circ} 1^{\prime} 40^{\prime \prime} \mathrm{S}$. Fig. 1 shows the Köppen climate

96 types of Brazil (adapted by the authors). In Brazil, 93\% of the landmass is in the Southern

97 Hemisphere (below Equator Line), and the remaining 7\% is in the Northern Hemisphere. This puts

98 all but the southernmost part of the country in the planet's tropical zone. The subtropical region,

99 which lies below the Tropic of Capricorn, contains $6.76 \%$ of the population. In this work, the term

100 (sub)tropical means both subtropical and tropical Brazilian climates, respectively. In Fig. 2

101 (Alvares et al., 2013), tropical climates like that of Amazonas appear in dark blue, while red dots

102 signify COVID-19 outbreaks, which are especially concentrated in coastal towns.

\subsection{Data Collection}

105 The study population is the total cumulative daily number of confirmed cases of COVID-19 in the 106 27 state capitals, as officially reported by the Ministry of Health of Brazil from February $26^{\text {th }}$ to July $2^{\text {nd }}, 2020$. This work focused on the capital cities because of Brazil's vast territory and the lack of climatic data for the interior cities of the Brazilian states. Daily meteorological means were collected from the National Institute of Meteorology (INMET) for the period of study. The estimated 2019 population was derived from the Brazilian Institute of Geography and Statistics (IBGE), the official provider of geographic and statistical information in Brazil. The classification

112 in subtropical and tropical climates follows Köppen climate types. Three characters, where the

113 first indicates the climate zone and is defined by temperature and rainfall, symbolize the Köppen 114 climate types. The second considers the rainfall distribution, and the third is the seasonal 115 temperature variation. 


\subsection{Statistical Analysis}

118 A descriptive analysis was performed, with numerical variables described using means, standard 119 deviation, and distribution. A Generalized Additive Model (GAM) and Locally Estimated 120 Scatterplot Smoothing (LOESS) nonparametric models were used to calculate the relationships

121 between environmental factors and the logarithm of the number of daily cumulative confirmed 122 cases $(\operatorname{lgN})$ to fit equations and splines. GAM fits generalized additive models for parametric and 123 nonparametric regression and smoothing to explore linear and nonlinear weather effects and health 124 outcomes (Liu et al., 2020)(Wu et al., 2018). GAM can be useful to explore linear and nonlinear 125 weather effects and health outcomes (Zhu et al., 2020). Although GAM and LOESS use the same statistical technique loess by smoothing out the data in local neighborhoods, LOESS is able to capture significant smoothing features because the local regions are treated independently. While GAM imposes additive structure, requiring that cross sections of the fitted surface always have the same shape. The use of both techniques together are more suitable for exploring the data and visualizing the relationship between the dependent variable and the independent variables than traditional linear models. In some cases, LOESS can capture essentially smoothing featureless of GAM. The model equations were defined as follows:

$$
\left(y_{i t}\right)=\beta_{0}+\beta_{1}\left(T_{i t}\right)+s\left(T_{i t}\right)+\varepsilon_{i t}
$$

$$
\left(y_{i t}\right)=\beta_{0}+\beta_{1}\left(r h_{i t}\right)+s\left(r h_{i t}\right)+\varepsilon_{i t}
$$

$$
\left(y_{i t}\right)=\beta_{0}+\beta_{1}\left(T_{i t}\right)+\beta_{2}\left(r h_{i t}\right)+s\left(T_{i t}\right)+s\left(r h_{i t}\right)+\varepsilon_{i t}
$$

136 These equations from (1) to (3) show the daily cumulative COVID-19 counts per 100K inhabitants $137\left(y_{i t}\right)$ in capital city $i$ on day $t$, considering the corresponding daily mean temperature $\left(T_{i t}\right)$ and 138 daily mean relative humidity $\left(r h_{i t}\right) . \beta_{0}$ is the intercept, $\beta_{1}$ and $\beta_{2}$ are the parameters of linear $\left(T_{i t}\right)$ 
139 or $\left(r h_{i t}\right)$, and $s(\cdot)$ denotes a spline function with a maximum of two degrees of freedom to avoid 140 overfitting (Liu et al., 2020).

141 In equation (1), daily cumulative COVID-19 counts per $100 \mathrm{~K}$ inhabitants $\left(y_{i t}\right)$ is calculated 142 considering just the daily mean temperature $\left(T_{i t}\right)$. Whereas, in equation (2), daily cumulative 143 COVID-19 counts per $100 \mathrm{~K}$ inhabitants $\left(y_{i t}\right)$ is calculated considering just the daily mean relative 144 humidity $\left(r h_{i t}\right)$. Finally, in equation (3), daily cumulative COVID-19 counts per 100K inhabitants $145\left(y_{i t}\right)$ is calculated considering daily mean temperature $\left(T_{i t}\right)$ and the daily mean relative humidity $146\left(r h_{i t}\right)$ simultaneously.

147 The GAM and Loess models were built in SAS ${ }^{\mathrm{TM}}$ software, with two-sided tests, and $\mathrm{p}<0.05$ was 148 considered statistically significant.

\section{Results}

\subsection{Descriptive Analysis}

153 Between February 26 $6^{\text {th }}$ and July $2^{\text {nd }}, 2020$ (129 days), 2,990 (N) observations were collected. Table 1541 summarizes the daily cumulative confirmed cases and the meteorological variables. The mean estimated population for the 27 capital cities in 2019 was 1,953,711 inhabitants. The respective daily means for relative humidity and temperature were $74.45 \%$ and $23.85^{\circ} \mathrm{C}$. The daily mean of cumulative confirmed cases was 5,738. Table 2 displays the total number of confirmed cases of COVID-19 per 100k habitants (incidence), which includes the Pearson correlation coefficients in the cases. The incidence of COVID-19 registered significantly positive Pearson correlations with a daily mean temperature of $\left(\mathrm{r}_{\mathrm{p}}=\right.$ $0.15437, \mathrm{p}<0.0001)$ and a daily mean relative humidity of $\left(\mathrm{r}_{\mathrm{p}}=0.25090, \mathrm{p}<0.0001\right)$. However, 
162 the nonparametric Spearman's correlation was negative to daily mean temperature of $\left(\mathrm{r}_{\mathrm{s}}=\right.$ $163-0.08075, \mathrm{p}=0.0009)$ and a positive daily mean relative humidity of $\left(\mathrm{r}_{\mathrm{s}}=0.20703, \mathrm{p}<0.0001\right)$.

164 The negative nonparametric result of Spearman's correlation has also given the intuition to explore

165 linear and nonlinear weather effects on the analysis.

166

167

168

169

170

171

172

173

174

175

176

177

178

179

180

181

182

183

184

185

\subsection{Dose-Response Relationship}

The dose-response relationships among temperature and humidity for (sub)tropical climates are shown in Fig. 3, where nonparametric and linear trends were analyzed by GAM models considering equations (1) and (2) and the LOESS model considering equation (3), with all of these equations stated in section 2.3.

A positive correlation emerged between daily mean temperature and incidence of COVID-19 in tropical regions, while the inverse was true in subtropical regions. The dose-response relationships of temperature (Fig.3 (A)) and relative humidity (Fig.3 (B)) by the LOESS regression model. The dose-response relationships of daily means of temperature (Fig.3, (C) subtropical, (D) tropical) and relative humidity (Fig. 3, (E) subtropical, (F) tropical) by the univariate GAM model. The bivariate smoothing of the daily means of temperature (Fig. $3(\mathrm{G})$ ) and relative humidity (Fig. 3 (H)) by the LOESS model.

The incidence of COVID-19 cases is correlated for each degree Celsius in temperature and each percentage point in relative humidity. Every $1^{\circ} \mathrm{C}$ rise of the daily temperature mean correlated with a $-11.76 \%(t=-5.71, \mathrm{p}<0.0001)$ decrease and a 5.66\% $(\mathrm{t}=5.68, \mathrm{p}<0.0001)$ increase in the incidence of COVID-19 for (sub)tropical climates, respectively. And, a positive correlation emerged between daily mean humidity and incidence of COVID-19 for both (sub)tropical regions. Each $1 \%$ rise of the daily relative humidity mean was associated with a $1.89 \%(t=2.35, p=0.0193)$ and a $1.17 \%(\mathrm{t}=4.60, \mathrm{p}<.0001)$ increase of COVID-19 for (sub)tropical climates, respectively. 
187 3.3 Sensitivity Analysis: The Lag of Days

188 The splines of the lags of 14 and 21 days for the daily temperature and relative humidity means 189 retain the same linearity in Fig. 3 above. For this reason, the study here plotted a LOESS fit to 190 capture distinct smoothing features of the regression line (Fig. 4).

191 The concentration of cases for subtropical temperatures varies from approximately $15^{\circ} \mathrm{C}$ to $25^{\circ} \mathrm{C}$. 192 In this range, cases decrease as temperature rises (Fig. 4 (A) and (B)), for lags of 14 and 21 days. 193 In contrast, the tropical climate experiences a case increase as temperature rises, with cases peaking 194 between $24^{\circ} \mathrm{C}$ and $28^{\circ} \mathrm{C}$ (Fig. 4 (C) and (D)), for lags of 14 and 21 days.

195 For relative humidity, in general, incidence grows from $40 \%$ onwards in both subtropical and 196 tropical climates, as shown in Fig. 4 from (E) to (H), for lags of 14 and 21 days.

\subsection{Sensitivity Analysis: Seasonal Change}

During this data analysis, Brazil transitioned from summer to winter. Therefore, it follows that since the first outbreak in the summer month of February, the temperature had decreased day by 201 day as winter arrived, while cases increased (Fig. 5 (A)).

The biased slope of temperature was $-0.017620(\mathrm{~F}=54.97, \mathrm{p}<.0001)$, which means that for each day along the $\mathrm{x}$-axis, the daily temperature decreased -0.017620 units. To offset bias in this analysis, the temperature data was adjusted as follows:

$$
T d_{i t}=T_{i t}+\left(\left(\text { CountDays }_{i}-1\right) * 0.017620\right)
$$

$T d_{i t}$ is the adjusted temperature in the capital city $i$ on day $t . T_{i t}$ is the observed temperature in the capital city $i$ on day $t$. The variable CountDays $_{i}$ are the days since the first outbreak in city $i$.

208 The biased slope of relative humidity (Fig. 5(B)) was $-0.032017(\mathrm{~F}=21.47, \mathrm{p}<.0001)$, and the 209 relative humidity data was adjusted as follows: 


$$
r h d_{i t}=r h_{i t}+\left(\left(\text { CountDays }_{i}-1\right) * 0.032017\right)
$$

211 rhd is the adjusted relative humidity in the capital city $i$ on day $t$. $r h$ is the daily observed relative

212 humidity in the capital city $i$ on day $t$. The variable count days are the days since the first outbreak 213 in city $i$.

214 In Fig. 5 (C) and (D), the bivariate smoothing of temperature and relative humidity can evidence 215 the spread of the incidence of COVID-19 over time.

216 After adjusting the biased slopes of temperature and relative humidity, the slopes changed to a 217 relatively flat regression lines of $-0.0002723(\mathrm{~F}=0.01, \mathrm{p}=0.9078)$, and $-0.0005267(\mathrm{~F}=0.01, \mathrm{p}$ $218=0.9394)$, respectively. The inverse relationship of temperature becomes even more clearly on 219 Fig. 6 (A) and (B) by the LOESS regression model, and in Fig. 6 (C) and (D) by the univariate 220 GAM model.

221 In Fig. $6(\mathrm{E})$ and $(\mathrm{F})$, the dose-response relationships of daily means of relative humidity remained 222 positive for the (sub)tropical climates, even after adjusting the biased slope. On Fig. $6(\mathrm{G})$ and $(\mathrm{H})$, 223 the bivariate smoothing of the daily means of temperature and relative humidity by the LOESS 224 model also revealed the inverse relationships for (sub)tropical climates.

225 Each $1^{\circ} \mathrm{C}$ rise of the mean daily adjusted temperature was associated with a $-6.89 \%(t=-2.99, \mathrm{p}$ $226=0.0029)$ decrease for subtropical climate and a $12.14 \%(t=12.35, \mathrm{p}<0.0001)$ increase in the 227 incidence of COVID-19 for the tropical climate. Each 1\% rise of the means daily adjusted relative 228 humidity was associated with a $2.35 \%(\mathrm{t}=4.17, \mathrm{p}<.0001)$ and a $2.26 \%(\mathrm{t}=8.88, \mathrm{p}<.0001)$ 229 increase of COVID-19 cases for both (sub)tropical climates, respectively.

230 Tables 3 and 4 summarize the effects of $1^{\circ} \mathrm{C}$ and $1 \%$ increases of daily temperature and relative 231 humidity, respectively, within the analyses. 
232 Consistent results of the sensitivity analyses yielded robust findings also including the lag of days.

233 As stated in (Zhu et al., 2020), the incubation period of COVID-19 combined with the delay of

234 Sars-CoV-2 testing results necessitated a moving-average approach to account for the cumulative

235 lag effect of temperature and relative humidity.

236

237 4. Discussion

238 The lack of scientific evidence on the environmental proliferation of COVID-19 in tropical countries prompted this investigation of the correlations between climatic variables and infectivity rates of SARS-CoV-2 through a Generalized Additive Model (GAM) and the Locally Estimated Scatterplot Smoothing (LOESS) nonparametric model. Approximately $83 \%$ of testing has been conducted in non-tropical countries $\left(30^{\circ} \mathrm{N}\right.$ and higher). Likewise, $\sim 90 \%$ of COVID-19 cases have been recorded in the same countries within a temperature range of $3^{\circ} \mathrm{C}$ to $17^{\circ} \mathrm{C}$.

Studies have shown a significant inverse relationship between temperature and relative humidity with the spread of SARS-CoV-2 (Bukhari \& Jameel, 2020)(Liu et al., 2020)(Zhu et al., 2020)(Núñez-Delgado, 2020)(Yip et al., 2007)(Thai et al., 2015)(Ng et al., 2014)(Lowen \& Steel, 2014)(Bi et al., 2007)(Barreca \& Shimshack, 2012)(Moriyama \& Ichinohe, 2019)(Casanova et al., 2010)(Wang et al., 2018)(Xu et al., 2020)(Daltio et al., 2018)(Chan et al., 2011)(van Doremalen et al., 2013). Recent studies have shown that SARS-CoV-2 has the highest predicted half-life at $30^{\circ} \mathrm{C}$ after drying, and virus titers remained more stable there over time than they did at lower temperatures (Kratzel et al., 2020). Another recent experiment revealed that the likelihood of survival for SARS-CoV-2 is roughly five times higher in humid conditions as it is in dry conditions

253 (Bhardwaj \& Agrawal, 2020). These studies are consistent with the spread of COVID-19 in Brazil 254 (Auler et al., 2020). 
255 Although respiratory droplets seem to play a central role in SARS-CoV-2 transmission (Anfinrud 256 et al., 2020), surface contact transmission has also been proven to have a significant impact on the

257 spread of the virus (Casanova et al., 2010)(Anfinrud et al., 2020). In addition, temperature and

258 humidity variations influence SARS-CoV-2 stability and survival (Duan et al., 2003). The virus

259 can remain active on surfaces from a few hours to several days, depending on these conditions

260 (van Doremalen et al., 2013).

261 The research findings by the use of Köppen climate types helped us to understand to what extent

262 the seasonal changes associated with climatic factors fluctuations might actively influence virus

263 survival. Köppen climate types are major classified by temperature and the distinction between

264 wet and dry climates. Until now, most of the cited studies are in temperate zones where the virus

265 found stability in dry and cold regions. This study showed that the virus also find stability in hot

266 and wet zones, like the tropical climate. It was possible because of the territorial magnitude of

267 Brazil, which include tropical, hot and wet, and subtropical, milder and dry, climates.

268 The observed data results have some limitations: other factors might influence findings, like

269 population density, virus resistance, population mobility and endurance, individual health factors,

270 and so on. While much about the virus remains a mystery, the growing body of research shows a

271 need for public safety measures to curtail its spread. These include social distancing, wearing

272 masks, using hand sanitizer, and quarantining, all of which may have directly impacted the findings

273 of this study. All of the Brazilian state capitals have at least employed some kind of social

274 distancing, but the long-term efficacy of these measures will require further study.

275

276 5. Conclusion

277 Findings revealed an inverse relationship between subtropical and tropical climates for the spread

278 of the novel coronavirus and temperature, suggesting a sensitivity behavior to climates zones, and 
279

280

281

282

283

284

285

286

287

288

289

290

291

292

293

294

295

296

297

298

299

300

301

302

303

304

305

306

307

308

309

310

311

312

313

314

315

perhaps hemispheres. Indeed, Köppen climate types do not follow latitudinal order to define climate zones. Outcomes conjecture a temperature pattern for the spread of COVID-19 for (sub)tropical climates, at least in Brazil, and may contribute to clarify the role of environmental factors for the spread of the novel coronavirus for different climate zones. Future climatic model studies should include solar variables such as geomagnetic or solar radiation, which have planetary incidence with space weather.

\section{References}

Alvares, C. A., Stape, J. L., Sentelhas, P. C., De Moraes Gonçalves, J. L., \& Sparovek, G. (2013). Köppen's climate classification map for Brazil. Meteorologische Zeitschrift, 22(6), 711-728. https://doi.org/10.1127/0941-2948/2013/0507

Anfinrud, P., Stadnytskyi, V., Bax, C. E., \& Bax, A. (2020). Visualizing Speech-Generated Oral Fluid Droplets with Laser Light Scattering. New England Journal of Medicine, 382(21), 2061-2063. https://doi.org/10.1056/NEJMc2007800

Auler, A. C., Cássaro, F. A. M., da Silva, V. O., \& Pires, L. F. (2020). Evidence that high temperatures and intermediate relative humidity might favor the spread of COVID-19 in tropical climate: A case study for the most affected Brazilian cities. Science of the Total Environment, 729. https://doi.org/10.1016/j.scitotenv.2020.139090

Barreca, A. I., \& Shimshack, J. P. (2012). Absolute humidity, temperature, and influenza mortality: 30 years of county-level evidence from the united states. American Journal of Epidemiology, 176(SUPPL. 7), 114-122. https://doi.org/10.1093/aje/kws259

Bedford, J., Enria, D., Giesecke, J., Heymann, D. L., Ihekweazu, C., Kobinger, G., Lane, H. C., Memish, Z., Oh, M., Sall, A. A., Schuchat, A., Ungchusak, K., \& Wieler, L. H. (2020). COVID-19: towards controlling of a pandemic. The Lancet, 395(10229), 1015-1018. https://doi.org/10.1016/S01406736(20)30673-5

Bhardwaj, R., \& Agrawal, A. (2020). Likelihood of survival of coronavirus in a respiratory droplet deposited on a solid surface. Physics of Fluids, 32(6), 061704. https://doi.org/10.1063/5.0012009

Bi, P., Wang, J., \& Hiller, J. E. (2007). Weather: Driving force behind the transmission of severe acute respiratory syndrome in China? Internal Medicine Journal, 37(8), 550-554. https://doi.org/10.1111/j.1445-5994.2007.01358.x

Bukhari, Q., \& Jameel, Y. (2020). Will Coronavirus Pandemic Diminish by Summer? SSRN Electronic Journal. https://doi.org/10.2139/ssrn.3556998

Campbell, U. (2020). Um retrato do colapso hospitalar em Manaus durante a pandemia. Época. https://epoca.globo.com/sociedade/um-retrato-do-colapso-hospitalar-em-manaus-durante-pandemia$1-24390212$

Casanova, L. M., Jeon, S., Rutala, W. A., Weber, D. J., \& Sobsey, M. D. (2010). Effects of air temperature and relative humidity on coronavirus survival on surfaces. Applied and Environmental 

Microbiology, 76(9), 2712-2717. https://doi.org/10.1128/AEM.02291-09

Chan, K. H., Peiris, J. S. M., Lam, S. Y., Poon, L. L. M., Yuen, K. Y., \& Seto, W. H. (2011). The effects of temperature and relative humidity on the viability of the SARS coronavirus. Advances in Virology, 2011. https://doi.org/10.1155/2011/734690

Costa, C. (2020). Covid-19 já matou em 1 mês e meio mais do que dengue, H1N1 e sarampo em todo 2019. O Globo. https://oglobo.globo.com/sociedade/coronavirus/covid-19-ja-matou-em-1-mesmeio-mais-do-que-dengue-h1n1-sarampo-em-todo-2019-24361190

Daltio, E., Gama, J., França, G., Prata, D., \& Veloso, G. (2018). The potential use of smartphone and social networks in public schools: A case study in north of Brazil. Proceedings of the 14th International Conference on Mobile Learning 2018, ML 2018.

Duan, S.-M., Zhao, X.-S., Wen, R.-F., Huang, J.-J., Pi, G.-H., Zhang, S.-X., Han, J., Bi, S.-L., Ruan, L., Dong, X.-P., \& SARS Research Team. (2003). Stability of SARS coronavirus in human specimens and environment and its sensitivity to heating and UV irradiation. Biomedical and Environmental Sciences : BES, 16(3), 246-255. http://www.ncbi.nlm.nih.gov/pubmed/14631830

Kratzel, A., Steiner, S., Todt, D., V'kovski, P., Brueggemann, Y., Steinmann, J., Steinmann, E., Thiel, V., \& Pfaender, S. (2020). Temperature-dependent surface stability of SARS-CoV-2. Journal of Infection, xxxx, 1-3. https://doi.org/10.1016/j.jinf.2020.05.074

Liu, J., Zhou, J., Yao, J., Zhang, X., Li, L., Xu, X., He, X., Wang, B., Fu, S., Niu, T., Yan, J., Shi, Y., Ren, X., Niu, J., Zhu, W., Li, S., Luo, B., \& Zhang, K. (2020). Impact of meteorological factors on the COVID-19 transmission: A multi-city study in China. Science of the Total Environment, 726, 138513. https://doi.org/10.1016/j.scitotenv.2020.138513

Lowen, A. C., \& Steel, J. (2014). Roles of Humidity and Temperature in Shaping Influenza Seasonality. Journal of Virology, 88(14), 7692-7695. https://doi.org/10.1128/jvi.03544-13

Moriyama, M., \& Ichinohe, T. (2019). High ambient temperature dampens adaptive immune responses to influenza A virus infection. Proceedings of the National Academy of Sciences of the United States of America, 116(8), 3118-3125. https://doi.org/10.1073/pnas.1815029116

Ng, S., Basta, N. E., \& Cowling, B. J. (2014). Association between temperature, Humidity and ebolavirus disease outbreaks in Africa, 1976 to 2014. Eurosurveillance, 19(35), 1-11. https://doi.org/10.2807/1560-7917.es2014.19.35.20892

Núñez-Delgado, A. (2020). What do we know about the SARS-CoV-2 coronavirus in the environment? Science of the Total Environment, 727, 138647. https://doi.org/10.1016/j.scitotenv.2020.138647

Prata, D. N., Rodrigues, W., \& Bermejo, P. H. (2020). Temperature significantly changes COVID-19 transmission in (sub)tropical cities of Brazil. Science of the Total Environment, 729, 138862. https://doi.org/10.1016/j.scitotenv.2020.138862

Saúde, M. da. (2020). Ministério da Saúde confirma primeiro caso de coronavírus no Brasil 26 de fevereiro de 2020. O Globo. https://g1.globo.com/ciencia-e-saude/noticia/2020/02/26/ministerio-dasaude-fala-sobre-caso-possivel-paciente-com-coronavirus.ghtml

Thai, P. Q., Choisy, M., Duong, T. N., Thiem, V. D., Yen, N. T., Hien, N. T., Weiss, D. J., Boni, M. F., \& Horby, P. (2015). Seasonality of absolute humidity explains seasonality of influenza-like illness in Vietnam. Epidemics, 13, 65-73. https://doi.org/10.1016/j.epidem.2015.06.002

van Doremalen, N., Bushmaker, T., \& Munster, V. J. (2013). Stability of middle east respiratory syndrome coronavirus (MERS-CoV) under different environmental conditions. Eurosurveillance, 18(38), 1-4. https://doi.org/10.2807/1560-7917.ES2013.18.38.20590

Wang, P., Goggins, W. B., \& Chan, E. Y. Y. (2018). A time-series study of the association of rainfall, 
relative humidity and ambient temperature with hospitalizations for rotavirus and norovirus infection among children in Hong Kong. Science of The Total Environment, 643, 414-422. https://doi.org/10.1016/j.scitotenv.2018.06.189

WHO. (2020). WHO Coronavirus Disease (COVID-19) Dashboard. https://covid19.who.int/

Wu, X., Lang, L., Ma, W., Song, T., Kang, M., He, J., Zhang, Y., Lu, L., Lin, H., \& Ling, L. (2018). Nonlinear effects of mean temperature and relative humidity on dengue incidence in Guangzhou, China. Science of the Total Environment, 628-629, 766-771. https://doi.org/10.1016/j.scitotenv.2018.02.136

Xie, J., \& Zhu, Y. (2020). Association between ambient temperature and COVID-19 infection in 122 cities from China. Science of the Total Environment, 724, 138201. https://doi.org/10.1016/j.scitotenv.2020.138201

Xu, Z., Shi, L., Wang, Y., Zhang, J., Huang, L., Zhang, C., Liu, S., Zhao, P., Liu, H., Zhu, L., Tai, Y., Bai, C., Gao, T., Song, J., Xia, P., Dong, J., Zhao, J., \& Wang, F. S. (2020). Pathological findings of COVID-19 associated with acute respiratory distress syndrome. The Lancet Respiratory Medicine, 8(4), 420-422. https://doi.org/10.1016/S2213-2600(20)30076-X

Yip, C., Chang, W. L., Yeung, K. H., \& Yu, I. T. S. (2007). Possible meteorological influence on the Severe Acute Respiratory Syndrome (SARS) community outbreak at Amoy Gardens, Hong Kong. Journal of Environmental Health, 70(3), 39-46.

Zhu, Y., Xie, J., Huang, F., \& Cao, L. (2020). Association between short-term exposure to air pollution and COVID-19 infection: Evidence from China. Science of the Total Environment, 727(December 2019), 138704. https://doi.org/10.1016/j.scitotenv.2020.138704 


\section{Table $\mathbf{1}$ (on next page)}

Descriptive statistics for the daily cumulative confirmed cases of COVID-19

Descriptive statistics for the daily cumulative confirmed cases of COVID-19 since the first outbreak in each city, and meteorological variables. 
1 Table 1. Descriptive statistics for the daily cumulative confirmed cases of COVID-19 since the

$2 \quad$ first outbreak in each city, and meteorological variables.

\begin{tabular}{lrrrrr}
\hline VARIABLE & N & MEAN & STD DEV & MINIMUM & MAXIMUM \\
\hline POPULATION & 2990 & 1953711 & 2560825 & 299127 & 12252023 \\
\hline CASES (CUMULATIVE) & 2990 & 5738.03 & 13015.10 & 1.00 & 129328 \\
\hline COUNTDAYS & 2990 & 56 & 32.27 & 1.00 & 129.00 \\
\hline T (DAILY) & 2578 & 23.85 & 3.95 & 6.57 & 32.53 \\
\hline RH (DAILY) & 2544 & 74.45 & 11.33 & 39.87 & 97.37
\end{tabular}

$3 \mathrm{~T}$ = daily mean Temperature. $\mathrm{RH}=$ daily mean Relative Humidity. $\mathrm{N}=$ Number of observations. 


\section{Table 2 (on next page)}

Pearson correlation coefficients for the incidence of COVID-19

Pearson correlation coefficients between the incidence of COVID-19 and daily Temperature and Relative Humidity, across all cities and days. 
1

2

Table 2. Pearson correlation coefficients between the incidence of COVID-19 and daily Temperature and Relative Humidity, across all cities and days.

\begin{tabular}{llll}
\hline VARIABLE & CASESH & T(D) & RH(D)
\end{tabular}

\begin{tabular}{lrrr}
\hline CASESH (N/HAB) & 1.000 & $\mathrm{~L} / \mathrm{NP}$ & $\mathrm{L} / \mathrm{NP}$ \\
\hline $\mathrm{T}(\mathrm{DAILY})\left({ }^{\circ} \mathrm{C}\right)$ & $0.15437^{*}$ & 1.000 & $\mathrm{~L} / \mathrm{NP}$ \\
\hline RH (DAILY) (\%) & $0.25090^{*}$ & $0.24334^{*}$ & 1.000
\end{tabular}

$3 * \mathrm{p}<0.0001, \mathrm{~L}-$ Significant Linear Correlation. NP - Significant Spearman's Non-Parametric Correlation. 4 


\section{Table 3 (on next page)}

The effects of a $1{ }^{\circ} \mathrm{C}$ T increase in the incidence of COVID-19 confirmed cases

The effects of a $1{ }^{\circ} \mathrm{C}$ increase in daily means of temperature on the incidence of COVID-19 confirmed cases 
1 Table 3. The effects of a $1{ }^{\circ} \mathrm{C}$ increase in daily means of temperature on the incidence of COVID219 confirmed cases Daily Temperature Mean from $6.57^{\circ} \mathrm{C}$ to $32.53^{\circ} \mathrm{C}$

\begin{tabular}{lcccccc}
\hline & \multicolumn{2}{c}{$\begin{array}{c}\text { Percentage } \\
\text { change }(\%)\end{array}$} & t-value & & p \\
& SUB & TROP & SUB & TROP & SUB & TROP \\
\cline { 2 - 7 } & -11.76 & 5.66 & -5.71 & 5.68 & $<0.0001$ & $<0.0001$ \\
\hline INCIDENCE & -6.18 & 6.26 & -2.94 & 6.29 & 0.0035 & $<0.0001$ \\
\hline INCIDENCE L0-07 & -8.95 & 5.83 & -4.25 & 5.84 & $<0.0001$ & $<0.0001$ \\
\hline INCIDENCE L0-14 & -6.89 & 12.14 & -2.99 & 12.35 & 0.0029 & $<0.0001$ \\
\hline INCIDENCE ADJUSTED & & & & & & \\
\hline
\end{tabular}

3 


\section{Table 4 (on next page)}

The effects of a 1\% RH increase in the incidence of COVID-19 confirmed cases

The effects of a $1 \%$ increase in mean relative daily humidity on the incidence of COVID-19 confirmed cases 
1

2

Table 4. The effects of a $1 \%$ increase in mean relative daily humidity on the incidence of COVID-19 confirmed cases

Mean Relative Daily Humidity from $39.87 \%$ to $97.37 \%$

\begin{tabular}{lrrrrrcc}
\hline & \multicolumn{2}{c}{$\begin{array}{c}\text { Percentage } \\
\text { change }(\%)\end{array}$} & \multicolumn{2}{c}{ t-value } & \multicolumn{2}{c}{$\mathrm{p}$} \\
\cline { 2 - 7 } & SUB & TROP & SUB & TROP & SUB & TROP \\
\hline INCIDENCE & 1.89 & 1.17 & 2.35 & 4.60 & 0.0193 & $<0.0001$ \\
\hline INCIDENCE L0-07 & $1.25^{*}$ & 1.65 & 1.51 & 6.46 & 0.1309 & $<0.0001$ \\
\hline INCIDENCE L0-14 & 3.41 & 2.46 & 4.13 & 9.70 & $<0.0001$ & $<0.0001$ \\
\hline INCIDENCE ADJUSTED & 3.36 & 1.93 & 4.30 & 7.55 & $<0.0001$ & $<0.0001$
\end{tabular}

$3 *^{*}$ no statistical significance for the subtropical lag of 7 days; however, $p$ of the lag of 14 days is $<.0001$. 
Figure 1

Schematic research design

Facts, Hypothesis, Methods, and Findings. 


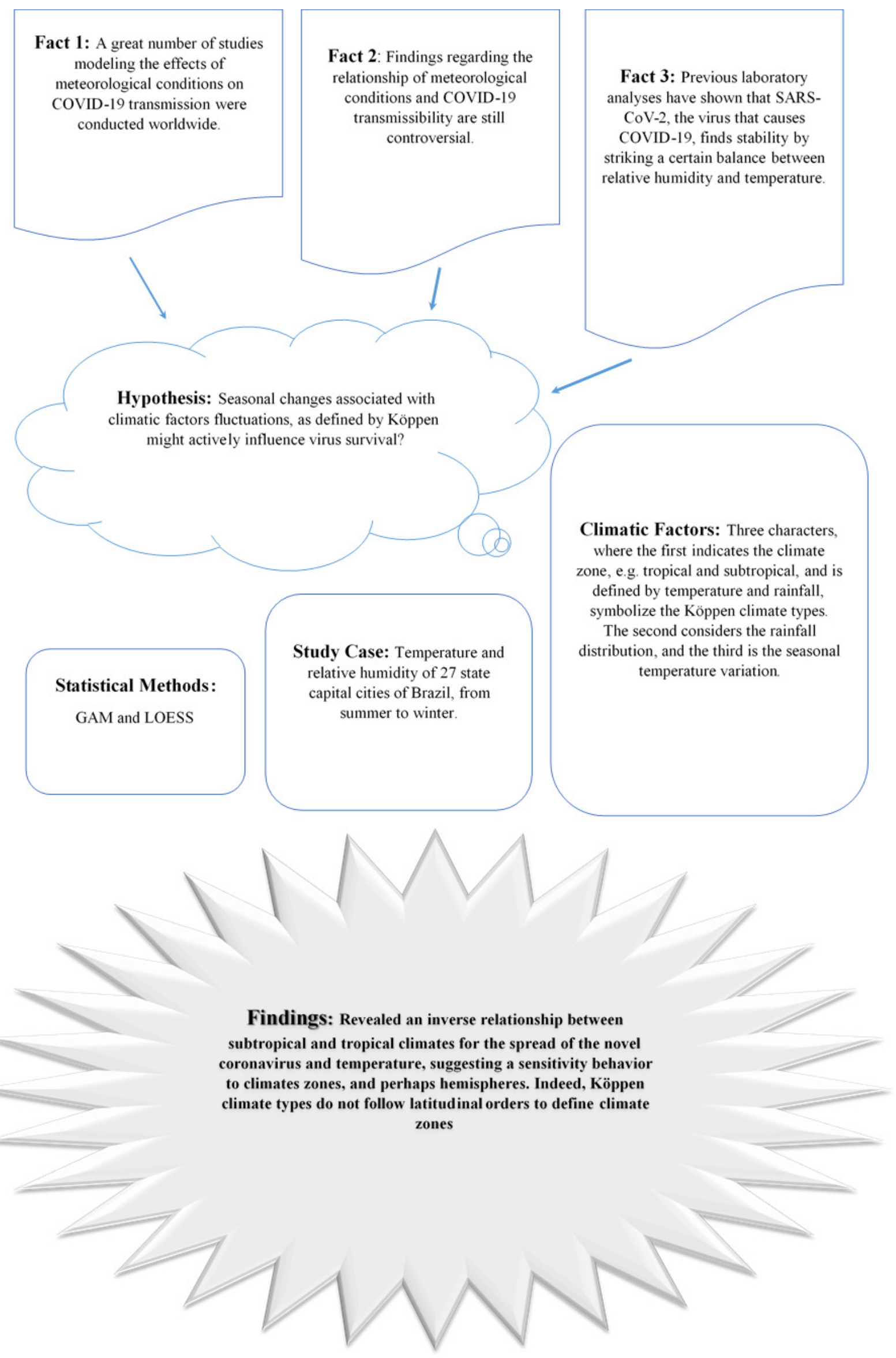




\section{Figure 2}

\section{COVID-19 IN STATE CAPITAL CITIES OF BRAZIL}

On the left, COVID-19 incidence by state capitals. On the right, Köppen Climate Types of Brazil (From Alvares et al., 2014; adapted by Authors) and confirmed cases of COVID-19.

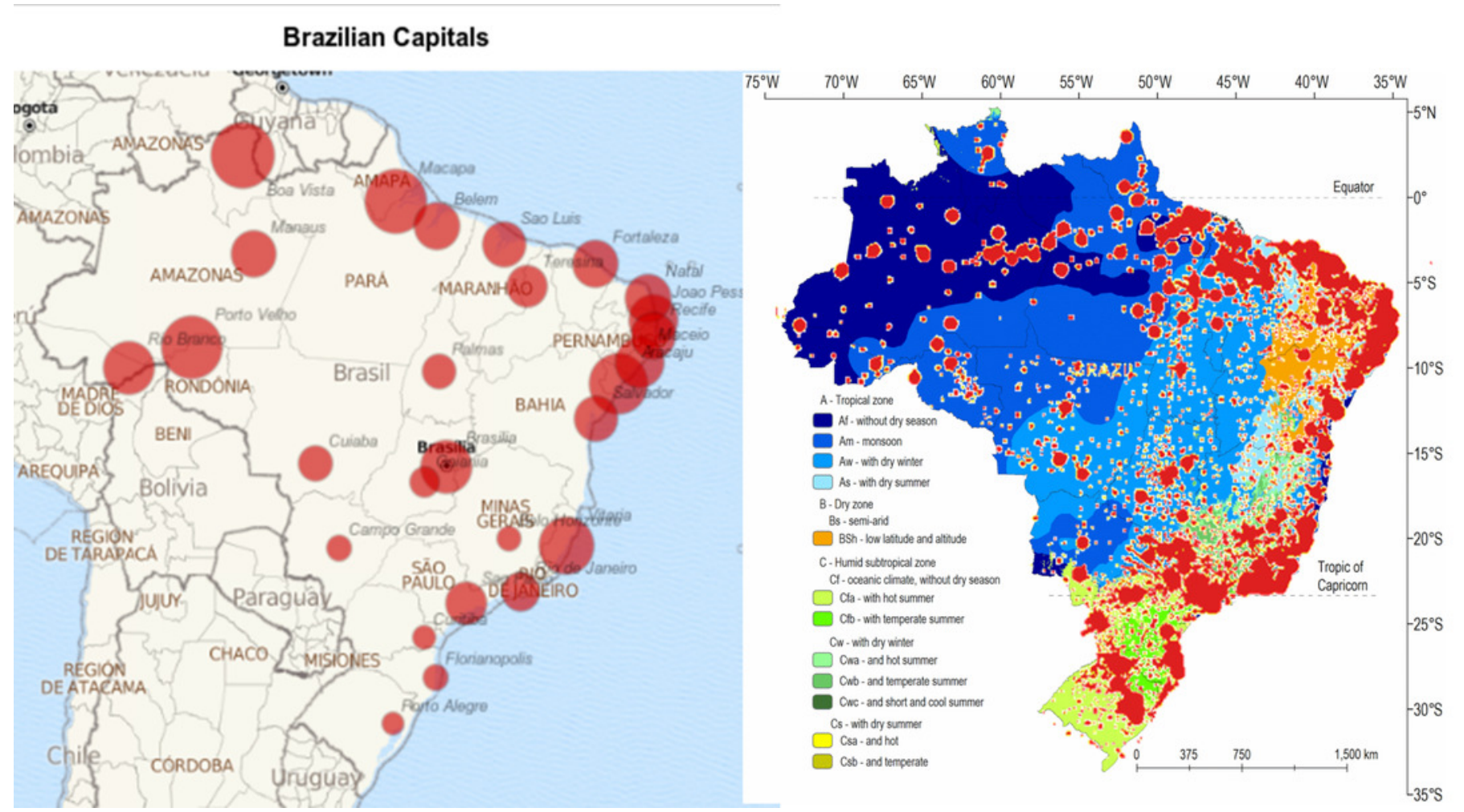


Figure 3

DOSE-RESPONSE RELATIONSHIPS FOR THE INCIDENCE OF COVID-19

The dose-response relationships of temperature and relative humidity by the GAM and LOESS regression models, and the LOESS bivariate smoothing. 

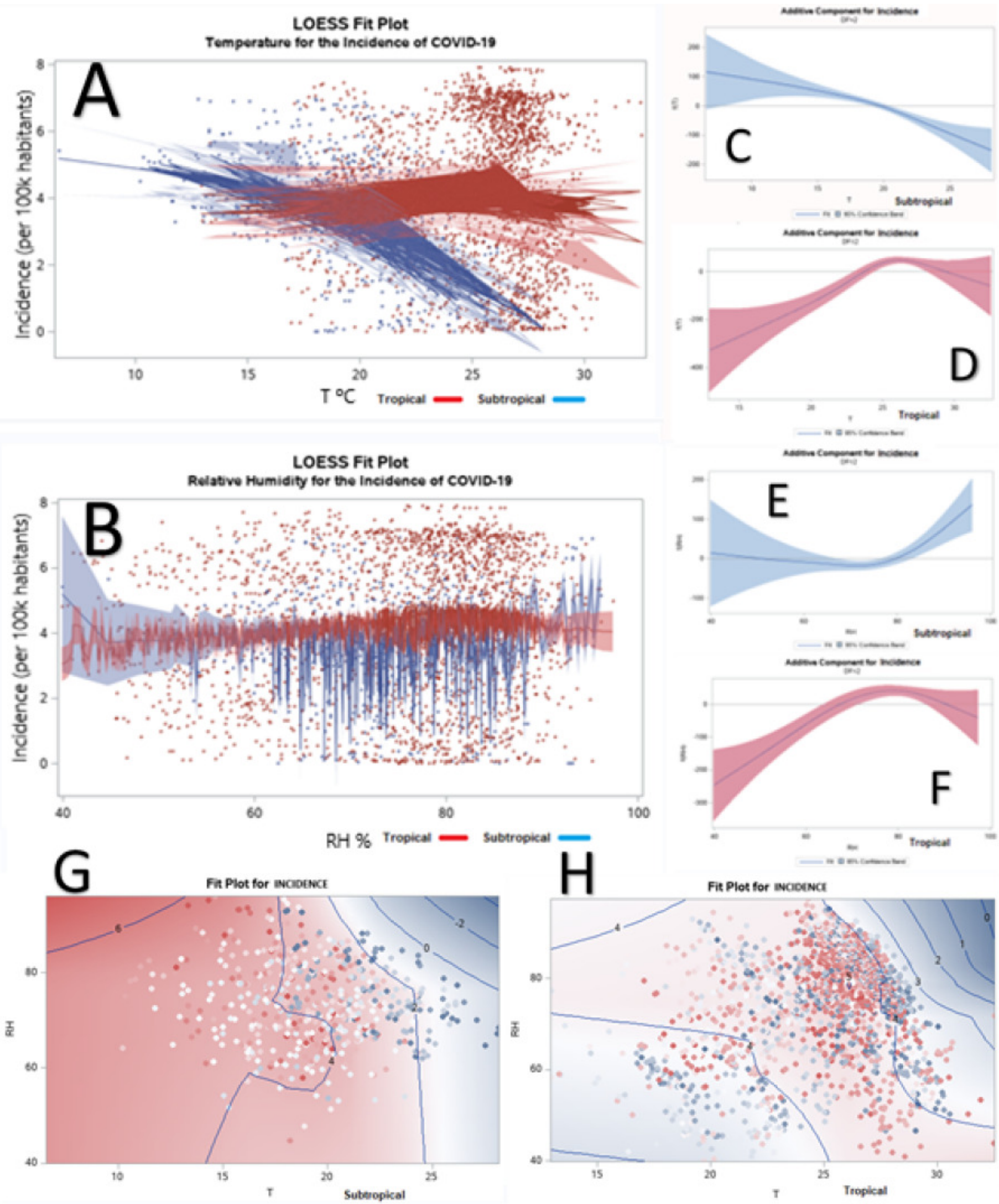
Figure 4

\section{THE LAG OF DAYS FOR THE DOSE-RESPONSE RELATIOSHIP}

The dose-response relationship of temperature and relative humidity for lags of 14 and 21 days by (sub)tropical regions. 

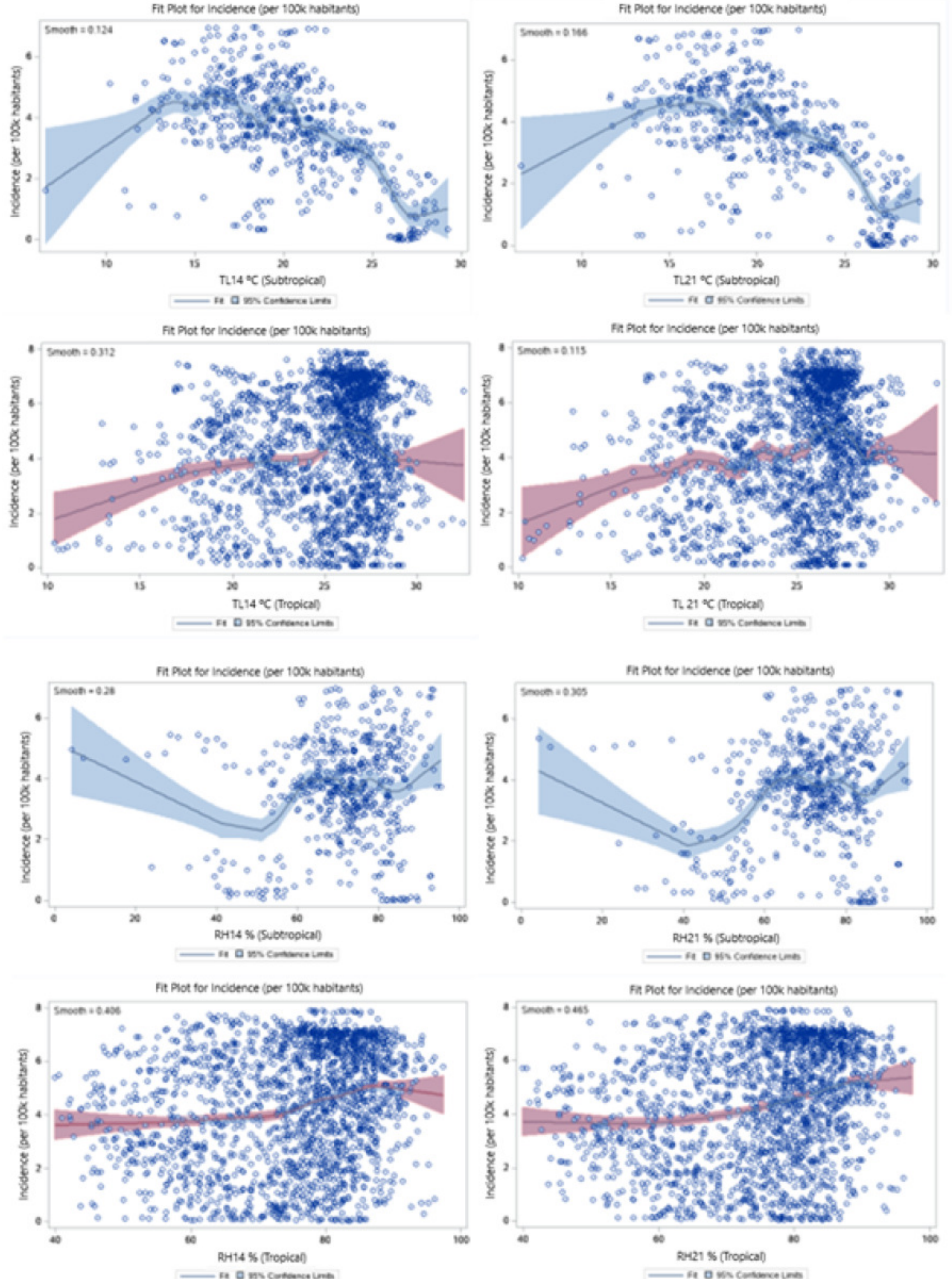


\section{Figure 5}

\section{DAILY MEAN TEMPERATURE AND RELATIVE HUMIDITY BY TIME ACROSS SEASONS}

The regression line for mean daily temperature and relative humidity along time. And, the bivariate smoothing of temperature and relative humidity for the spread of the incidence of COVID-19 over time.
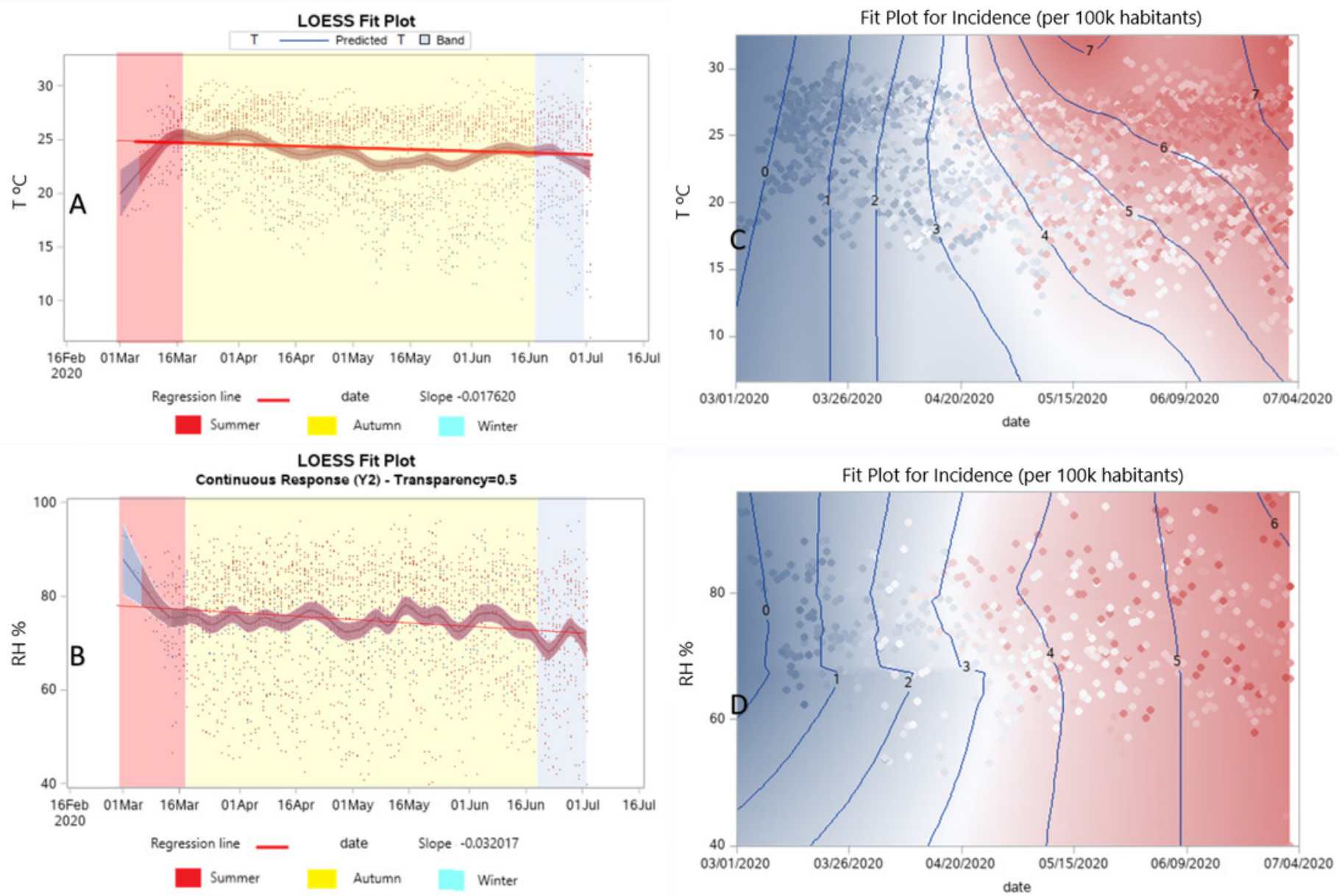
Figure 6

\section{DOSE-RESPONSE RELATIOSHIPS REGARDING SEASONAL CHANGE}

The dose-response relationships of temperature and relative humidity by the GAM and LOESS regression models. And, the bivariate smoothing of the daily means of temperature and relative humidity by the LOESS model. 

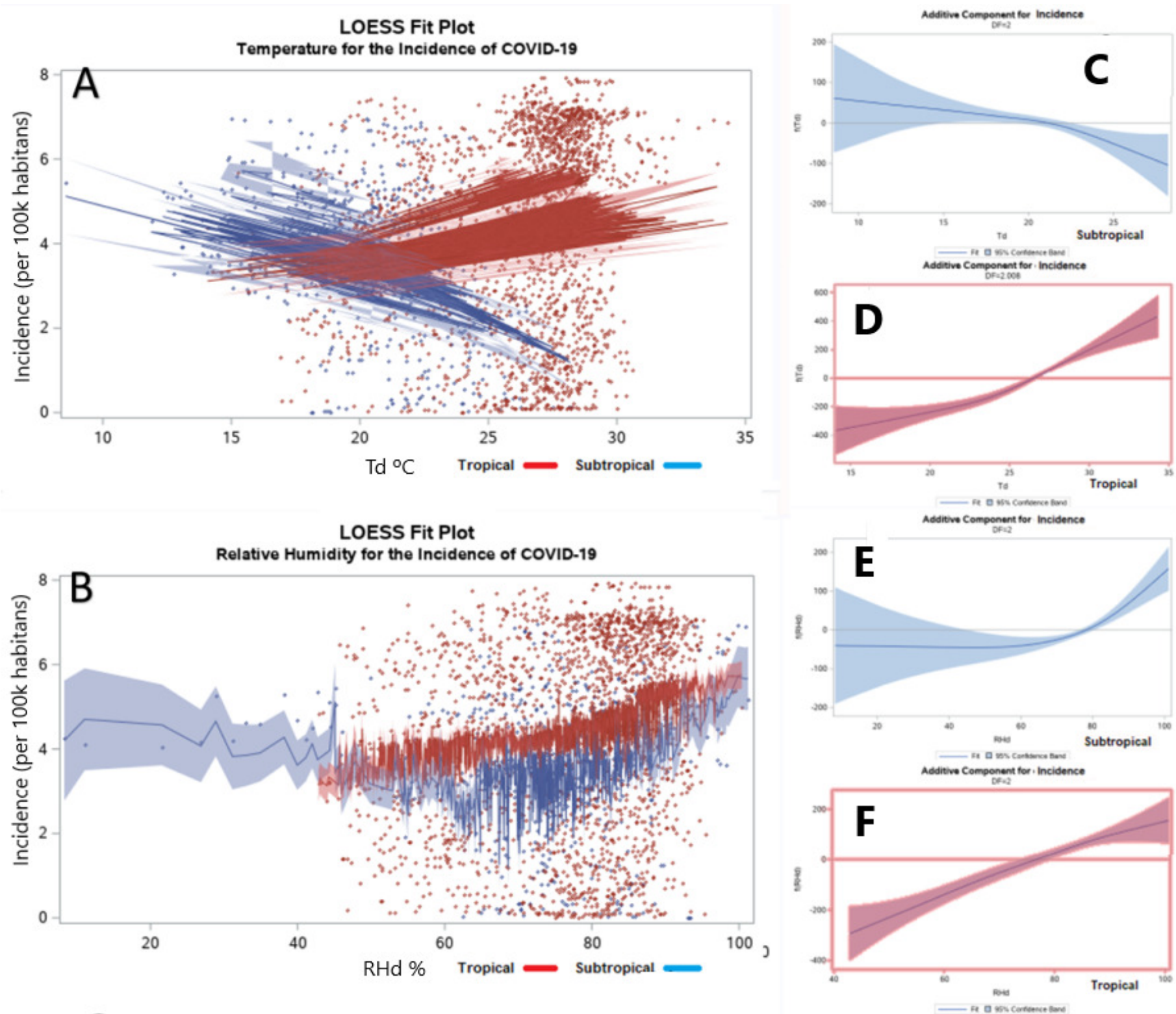

G Fit Plot for Incidence (per 100k habitants)
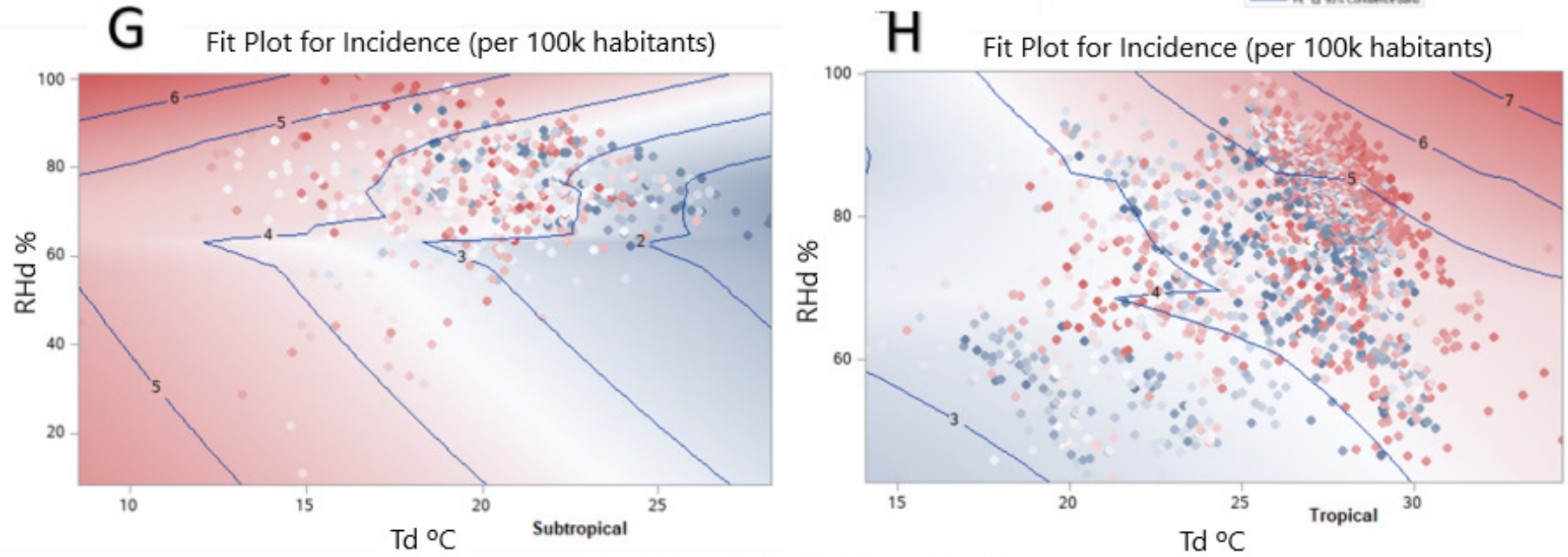

Fig. 5. Dose-response relotionships reganding seasonal change. 